\title{
A novel RFLP-ARMS TaqMan PCR-based method for detecting the BRAF V600E mutation in melanoma
}

\author{
YUNQING ZHANG $^{1 *}$, SHOUFANG QU ${ }^{2 *}$, JINYIN ZHAO $^{3}$, TING YU $^{2}$, LIPING GUO $^{3}$, \\ SONGCHAO YIN ${ }^{1}$, XIAOXU HU ${ }^{3}$, WEIJUN CHEN ${ }^{3,4}$, WEI LAI ${ }^{1}$ and JIE HUANG ${ }^{2}$ \\ ${ }^{1}$ Department of Dermatology, The Third Affiliated Hospital of Sun Yat-sen University, Guangzhou, Guangdong 510630; \\ ${ }^{2}$ Division of In Vitro Diagnostic Reagents, National Institutes for Food and Drug Control, Beijing 100050; \\ ${ }^{3}$ Key Laboratory of Genome Sciences and Information, Beijing Institute of Genomics, \\ Chinese Academy of Sciences, Beijing 100101; ${ }^{4}$ Beijing BGI-GBI Biotech Co., Ltd, Beijing 101300, P.R. China
}

Received January 2, 2017; Accepted January 19, 2018

DOI: $10.3892 / \mathrm{ol} .2018 .8844$

\begin{abstract}
To enable the rapid and sensitive screening of the BRAF V600E mutation in clinical samples, a novel method combining restriction fragment length polymorphism (RFLP) analysis with the popular amplification refractory mutation system (ARMS) TaqMan quantitative (qPCR) genotyping method in a single reaction tube was developed. A total of 2 primer pairs were designed to enrich for and genotype the BRAF mutational hotspot (RFLP primers and ARMS primers) and a restriction enzyme was used to remove the wild-type alleles. The analysis revealed that this method detected mutant alleles in mixed samples containing $>0.1 \%$ mutant sequences. In a survey of 53 melanoma samples, this method detected 21 mutation-positive samples. This novel RFLP-ARMS TaqMan qPCR protocol may prove useful for detecting mutations in clinical samples containing only a small proportion of mutant alleles.
\end{abstract}

\section{Introduction}

BRAF is one of the most frequently mutated protein kinases in human cancer $(1,2)$. BRAF protein kinase has been suggested to be among the most likely protein kinase genes to carry

Correspondence to: Dr Wei Lai, Department of Dermatology, The Third Affiliated Hospital of Sun Yat-sen University, 600 Tianhe Road, Guangzhou, Guangdong 510630, P.R. China

E-mail: drlaiwei@163.com

Mr. Jie Huang, Division of In Vitro Diagnostic Reagents, National Institutes for Food and Drug Control, 2 West Temple of Heaven, Beijing 100050, P.R. China

E-mail: jhuang5522@126.com

*Contributed equally

Key words: B-Raf proto-oncogene, serine/threonine kinase, V600E, restriction fragment length polymorphism-amplification refractory mutation system TaqMan polymerase chain reaction, melanoma driver mutations (3). BRAF mutations have been identified in the majority of malignant melanomas, and the frequency of BRAF mutations in malignant melanomas is $59 \%$ (1). The mutation frequency of BRAF is relatively low in other types of cancer, including papillary thyroid carcinoma and colorectal carcinoma. Research by Davies and his colleagues indicated that the BRAF mutation is a novel diagnostic and prognostic biomarker in thyroid cancer by analyzing cytological and histological thyroid samples, which occurs specifically and with a high prevalence $(35.8 \%)$ in papillary thyroid carcinoma, followed by colorectal carcinoma (18\%), gliomas $(11 \%)$, sarcomas (9\%), ovarian carcinomas $(4 \%)$ and lung cancer (3\%) (1). Mutations in BRAF have been associated with altered sensitivities to numerous drugs, including PLX4720, Nutlin-3a, AZ628, bortezomib, embelin, RDEA119, FH535, CI-1040, CHIR-99021, AP-24534, obatoclax mesylate, PF-562271, CEP-701, FTI-277, 17-AAG, PD-0325901, SB590885, AZD6244, PD-173074, ZM-447439, BIBW2992, temsirolimus, metformin, AZD6482 and gefitinib (http://cancer. sanger.ac.uk/cancergenome/projects/cosmic/; visited March 10th, 2014.). The most notable mutational hotspot for BRAF is p.V600E (c.1799T >A), which accounts for $\sim 90 \%$ of the known cancer-associated mutations (4).

The BRAF V600E mutation is strongly associated with significantly improved treatment response (5-7). Therefore, it is considered important to screen for this mutation prior to selecting a therapeutic strategy. However, it has proven challenging to determine the status of this mutation in clinical samples $(8,9)$. A major problem has been that the mutant cells are typically outnumbered by numerous surrounding wild-type cells at the tissue sampling site $(8,9)$. A number of methods have been developed to overcome this problem, including those based on restriction fragment length polymorphism (RFLP) analysis $(10,11)$, matrix-assisted laser desorption/ionization time-of-flight mass spectrometry analysis (12), ligase chain reaction (13), suspension array (14), amplification refractory mutation system polymerase chain reaction (ARMS PCR) (15-19), allele-specific enzymatic amplification (20), mutant-enriched PCR $(11,21)$, pyrosequencing (22), coamplification at lower denaturation temperature PCR (COLD-PCR) (23-27), high resolution 
melting $(28,29)$, fluorescent amplicon generation (30), locked nucleic acid/peptide nucleic acid clamp PCR $(31,32)$, anti-primer quenching-based quantitative (qPCR) (33) and SNaPshot analysis (34-36).

Among these techniques, RFLP and ARMS PCR are widely used $(37,38)$. Restriction enzymes specifically digest wild-type alleles, leaving the mutant alleles available for analysis. This approach has been successfully used to detect mutations in tumor protein 53, Ras and epithelial growth factor receptor (11,39-41). ARMS PCR is based on the principle that extension is efficient when the $3^{\prime}$ terminal base of a primer matches its target, but inefficient or nonexistent when the $3^{\prime}$ terminal base is mismatched. Therefore, when primers are designed against the mutation of interest, amplification proceeds only if the mutation is present (38). This strategy has been successfully used to screen for point mutations (42-44). However, RFLP analysis involves a number of post-PCR processing steps, which may increase the risk for contamination of the PCR product $(10,11)$, and the usefulness of the ARMS method may be limited by inefficient amplification due to the abundance of wild-type alleles (19).

The present study describes a novel method that combines RFLP analysis and ARMS TaqMan qPCR in a one-step reaction tube, and suggests the use of this technique, termed 'RFPL-ARMS TaqMan PCR,' to screen clinical melanoma samples for the BRAF V600E mutation.

\section{Materials and methods}

Plasmid construction. Recombinants plasmids encoding wild-type and V600E mutant BRAF were constructed as described by Board et al (44). Briefly, corresponding outer and mutant primers were used to yield half fragments with complimentary ends using wild type tissue DNA as a template (first half primer sequences: forward, 5'-CCAGGAGTGCCA AGAGAATA-3', and reverse, 5'-CCATCGAGATTTCTCTGT AGCTAGACCA-3'; second half primer sequences, forward, 5'-TGGTCTAGCTACAGAGAAATCTCGATGG-3', and reverse, 5'-TTTCAACAGGGTACACAGAACA-3'), with each half fragment containing a mutant base. PCR was performed in a $50 \mu 1$ mixture containing $5 \mu \mathrm{l}$ 10X PCR Buffer (Takara Bio Inc., Otsu, Japan), 1.25 U Takara TaqTM polymerase (Takara Bio Inc.), $4 \mu 1$ dNTP mixture (Takara Bio Inc.), $0.5 \mu \mathrm{M}$ primers and $5 \mu \mathrm{l}$ DNA (Sigma-Aldrich, Merck KGaA, Darmstadt, Germany). The reaction procedure was as follows: Initial denaturation at $95^{\circ} \mathrm{C}$ for $5 \mathrm{~min}$, followed by 35 cycles at $95^{\circ} \mathrm{C}$ for $15 \mathrm{sec}$, primer annealing at $53^{\circ} \mathrm{C}$ for $20 \mathrm{sec}$, and $72^{\circ} \mathrm{C}$ for $50 \mathrm{sec}$, final extension took place at $72^{\circ} \mathrm{C}$ for $5 \mathrm{~min}$. The two half fragment products were mixed equally as a template for the second round PCR. The second round of PCR used inner nested primers (forward, 5'-AGCATCTTCATTCCAATG AAGAGCC-3', and reverse, 5'-CATCCACAAAATGGATCC AGACAAC-3'. The second round was performed in a $50 \mu \mathrm{l}$ mixture containing $5 \mu \mathrm{l}$ 10X PCR Buffer (Takara Bio Inc.), 1.25 U Takara TaqTM polymerase (Takara Bio Inc.), $4 \mu \mathrm{l}$ dNTP mixture (each $2.5 \mathrm{mM}$; Takara Bio Inc., ), $0.5 \mu \mathrm{M}$ primers and $5 \mu 1$ template. The thermocycling conditions included initial denaturation at $95^{\circ} \mathrm{C}$ for $5 \mathrm{~min}$, followed by 40 cycles of $95^{\circ} \mathrm{C}$ for $15 \mathrm{sec}, 50^{\circ} \mathrm{C}$ for 30 and $72^{\circ} \mathrm{C}$ for $50 \mathrm{sec}$, the final extension took place at $72^{\circ} \mathrm{C}$ for $5 \mathrm{~min}$. Self-priming of the complementary half fragments and the subsequent amplification created a final product harboring the mutant base. The products were ligated into the pMD19 plasmid (Takara Bio Inc., Otsu, Japan), and recombinants containing mutant alleles were produced and confirmed by sequencing performed by Sangon Biotech Co., Ltd., (Shanghai, China). The sequencing machine used was ABl-PRISM 3,730 (Applied Biosystems; Thermo Fisher Scientific, Inc., Waltham, MA, USA) and the analysis software was DNASTAR 5.0 (DNASTAR, Inc., Madison, WI, USA). Recombinant plasmid DNA was extracted using a Tiangen Plasmid DNA kit (Tiangen Biotech Co., Ltd., Beijing, China). As a positive control, the recombinants were mixed with an equal amount of human genomic DNA (Sigma-Aldrich, Merck KGaA, Darmstadt, Germany).

Sample collection and DNA extraction. In total, 53 patients with melanoma treated at the Department of Dermatology, The Third Affiliated Hospital of Sun Yat-sen University (Guangzhou, China), were enrolled in the present study from March 2011 to December 2012. Unrelated patients diagnosed with melanoma were included. These samples were all biopsies. The median age of patients was 68 years (age range 39-84 years). A total of 33 cases (62\%) were females, and 20 cases $(38 \%)$ were males. A total of 10 patients (19\%) exhibited Clark level II disease (penetration of melanoma into the second layer of the skin, the dermis) (45), and 18 patients (34\%), 24 patients (45\%) and 1 patient (2\%) exhibited III, IV and $\mathrm{V}$ stage disease, respectively. The study protocol was approved by the Ethics Committee of The Third Affiliated Hospital of Sun Yat-sen University, and written informed consent was obtained from all patients. DNA was extracted from $10 \%$ formalin-fixed that was fixed at room temperature for $24 \mathrm{~h}$, paraffin-embedded melanoma samples using a QIAamp DNA FFPE Tissue kit (Qiagen GmbH, Hilden, Germany). Briefly, formalin-fixed, paraffin-embedded blocks containing the maximum number of tumor-rich areas from the patients were selected and sliced into $35-\mu \mathrm{m}$ thick sections. Each section was processed by proteinase $\mathrm{K}$ digestion at $56^{\circ} \mathrm{C}$ for $>16 \mathrm{~h}$, and the obtained lysate was loaded onto a QIAamp column. Following 2 washes, the DNA was eluted with $100 \mu \mathrm{l}$ $\mathrm{ddH}_{2} \mathrm{O}$. The extracted DNA was kept at $-20^{\circ} \mathrm{C}$ until it was used for PCR analysis.

RFLP-ARMS TaqMan PCR-based genotyping. The RFLP-ARMS TaqMan PCR assay described in the present study was a one-step PCR that used a mutation-enriching reaction and ARMS primer genotyping process to selectively eliminate wild-type genes and detect the mutant alleles. For the BRAF V600E mutation, a restriction enzyme was used to digest the wild-type genomic DNA, thereby enriching the mutant allele, and then a pair of RFLP primers: Forward, 5'-AGC ATCTTCATTCCAATGAAGAGCC-3'; and reverse, 5'-CAT CCACAAAATGGATCCAGACAAC-3', designed to amplify a 400-500 bp fragment containing the mutant allele [melting temperature $\left.(\mathrm{Tm}), 65^{\circ} \mathrm{C}\right]$, were used. The ARMS primers were designed to selectively amplify a mutant allele with a lower $\operatorname{Tm}\left(60^{\circ} \mathrm{C}\right)$ with the following respective sequences: Forward, 5'-TAGGTGATTTTGGTCTAGCTACACA-3' (mismatched base is underlined); and reverse, 5'-CCACAAAATGGATCC AGACAAC-3'. To improve the specificity of the ARMS primers, 
an additional mismatch base was introduced at the penultimate nucleotide of the mutation site ( $\mathrm{G}$ was replaced by $\mathrm{C}$ ), based on the principles described by Newton et al (19). Mutant allele enrichment and genotyping were performed in a single tube via a 3-phase reaction: i) $65^{\circ} \mathrm{C}$ for $30 \mathrm{~min}$, allowing the restriction enzyme, TspRI, to cut the wild-type DNA; ii) enrichment of the mutant allele with the RFLP primers and thermocycling conditions of $95^{\circ} \mathrm{C}$ for $10 \mathrm{~min}$, followed by 5 cycles of $95^{\circ} \mathrm{C}$ for $15 \mathrm{sec}, 65^{\circ} \mathrm{C}$ for $20 \mathrm{sec}$ and $72^{\circ} \mathrm{C}$ for $60 \mathrm{sec}$; and iii) selective amplification of the mutant allele with the ARMS primers, and 40 cycles of $95^{\circ} \mathrm{C}$ for $15 \mathrm{sec}$ and $60^{\circ} \mathrm{C}$ for $35 \mathrm{sec}$ (fluorescence collection). During the second phase, the ARMS primers were unable to bind at the higher temperature $\left(65^{\circ} \mathrm{C}\right)$, while in the third phase, the RFLP primers did not function as the 400-500 bp product was incompletely synthesized during the $35 \mathrm{sec}$ elongation phase.

The PCR reaction mixtures contained 12.5 $\mu \mathrm{l}$ TaqMan universal PCR MasterMix (Applied Biosystems; Thermo Fisher Scientific, Inc., Waltham, MA, USA), $0.2 \mu \mathrm{M}$ probe, $0.25 \mu \mathrm{M}$ primer (each), $3 \mu \mathrm{I}$ DNA, 5 IU TspRI (New England Biolabs, Inc., Ipswich, MA, USA), and $\mathrm{ddH}_{2} \mathrm{O}$ to $5 \mu \mathrm{l}$. qPCR was performed using an ABI7300 (Applied Biosystems; Thermo Fisher Scientific, Inc., Waltham, MA, USA). DNA samples were extracted from all clinical tissue samples using a QIAamp DNA FFPE Tissue kit (Qiagen GmbH, Hilden, Germany), and tested using our RFLP-ARMS TaqMan PCR detection system.

Specificity assay. To determine the specificity of the proposed RFPL-ARMS TaqMan PCR method, reactions were performed with 2-200 ng of wild-type genomic DNA (Sigma-Aldrich, Saint Louis, Missouri, USA) per reaction and assessed the inefficiency caused by extension from wild-type DNA. An internal control assay was used to assess the total DNA concentration from 2-200 ng in each sample. The forward primer was designed to begin at c.1798G; it amplified wild-type and V600E mutant BRAF using the aforementioned reverse primer and probe. The change in the threshold cycle $(\Delta \mathrm{Cq})[\Delta \mathrm{Cq}=($ mutation $\mathrm{Cq})-($ control $\mathrm{Cq})]$ was defined for each sample. The reactions were performed five times for each DNA concentration, and each reaction was repeated in triplicate to define a cut-off $\Delta \mathrm{Cq}$ value (46).

Assessing the detection limits of RFLP-ARMS TaqMan PCR. The wild-type and mutant plasmid DNA samples were diluted 10 -fold. The effective copy number of plasmids was obtained by comparing the $\mathrm{Cq}$ of the diluted samples with that obtained from Human Random Control DNA Panels (Sigma-Aldrich; Merck KGaA, Darmstadt, Germany) with a known concentration of $100 \mathrm{ng} / \mu \mathrm{l}$. In a high-quality DNA sample, there was an average of 1 set genomic DNA per $3 \mathrm{pg}$.

To assess the sensitivity of our assay for the BRAF V600E mutation, it was compared with the ARMS TaqMan PCR protocol without a removed enzyme digestion step. The mutant-encoding plasmid $(50,000,5,000,500,50$ or 5 copies) was mixed with wild-type genomic DNA (30 ng/ $\mu \mathrm{l})$, corresponding to $80,8,0.8,0.08$ and $0.008 \%$ mutation rate. For quantification, a standard curve was generated by plotting the $\mathrm{Cq}$ cycle numbers against the log of each corresponding DNA copy numbers for the known standards. The linear correlation coefficients $\left(\mathrm{R}^{2}\right)$ and slopes were calculated using
A
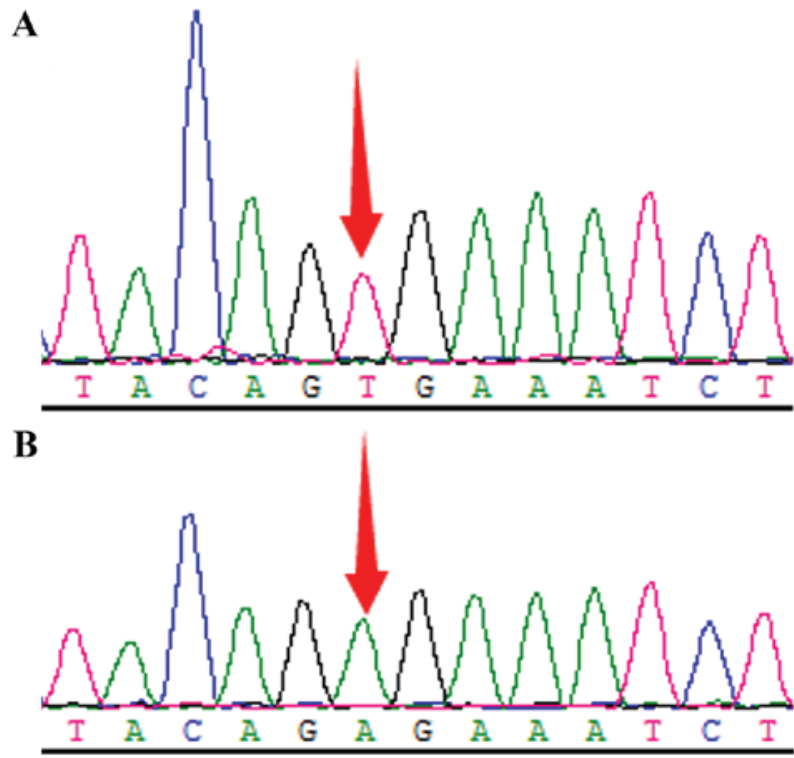

Figure 1. Comparison of results from the mutation-enriched PCR sequencing and direct PCR sequencing assays. (A) Direct PCR sequencing of the mimic human genomic DNA panel containing $1 \%$ V600E mutation, without mutant enrichment. (B) Mutation-enriched PCR sequencing of the same mimic human genomic DNA panel containing 1\% V600E mutation. PCR, polymerase chain reaction. Red arrows indicate mutation base location.

ABI7300 software (v.1.3; Applied Biosystems; Thermo Fisher Scientific, Inc.).

Genotyping by DNA sequencing. All samples were re-analyzed by PCR sequencing, described as following. Kimura et al (47) previously demonstrated that direct sequencing failed to yield satisfactory results from samples containing mixtures of wild-type and mutant DNA. In the present study, the existing mutation-enriched PCR sequencing method was improved by restriction enzyme selectively cutting wild type alleles and leaving the mutant alleles enriched, increasing the mutation rate. This method was adapted for the detection of the BRAF V600E mutation. This method involved a first PCR amplification step, enzymatic digestion (to remove the wild-type DNA), a second PCR step for mutant enrichment and a final sequencing step. PCR was performed in a total volume of $25 \mu \mathrm{l}$ containing $12.5 \mu \mathrm{l} 2 \mathrm{X}$ Gold Fast PCR mix (Tiangen Biotech Co., Ltd., Beijing, China), $0.4 \mu \mathrm{M}$ each primer (round 1: forward, 5'-AGCATCTTCATTCCAATGAAGAGCC-3', and reverse, 5'-CATCCACAAAATGGATCCAGACAAC-3'; round 2: forward, 5'-CATAATGCTTGCTCTGATAGGA-3', and reverse, 5'-CCACAAAATGGATCCAGACAAC-3') and $3 \mu \mathrm{l}$ DNA (for the first round of PCR) or $3 \mu 1$ digested product (for the second round of PCR). The cycling conditions consisted of $95^{\circ} \mathrm{C}$ for $10 \mathrm{~min}$, followed by 20 (round 1) or 35 (round 2) cycles of $95^{\circ} \mathrm{C}$ for $15 \mathrm{sec}, 58^{\circ} \mathrm{C}$ for $20 \mathrm{sec}$ and $72^{\circ} \mathrm{C}$ for $30 \mathrm{sec}$, with a final extension at $72^{\circ} \mathrm{C}$ for $7 \mathrm{~min}$ and a final hold at $4^{\circ} \mathrm{C}$. Following the first round of PCR, digestion of the wild-type product was performed in a $50 \mu \mathrm{l}$ volume containing $10 \mu \mathrm{l}$ first-round PCR product, $5 \mu \mathrm{l}$ 10X CutSmart Buffer (New England Biolabs, Inc., Ipswich, MA, USA) and 5 IU TspRI (New England Biolabs, Inc.) at $65^{\circ} \mathrm{C}$ for $30 \mathrm{~min}$. All of the obtained second-round PCR products were sequenced by Sangon Biotech Co., Ltd. (Shanghai, China). The sequencing 


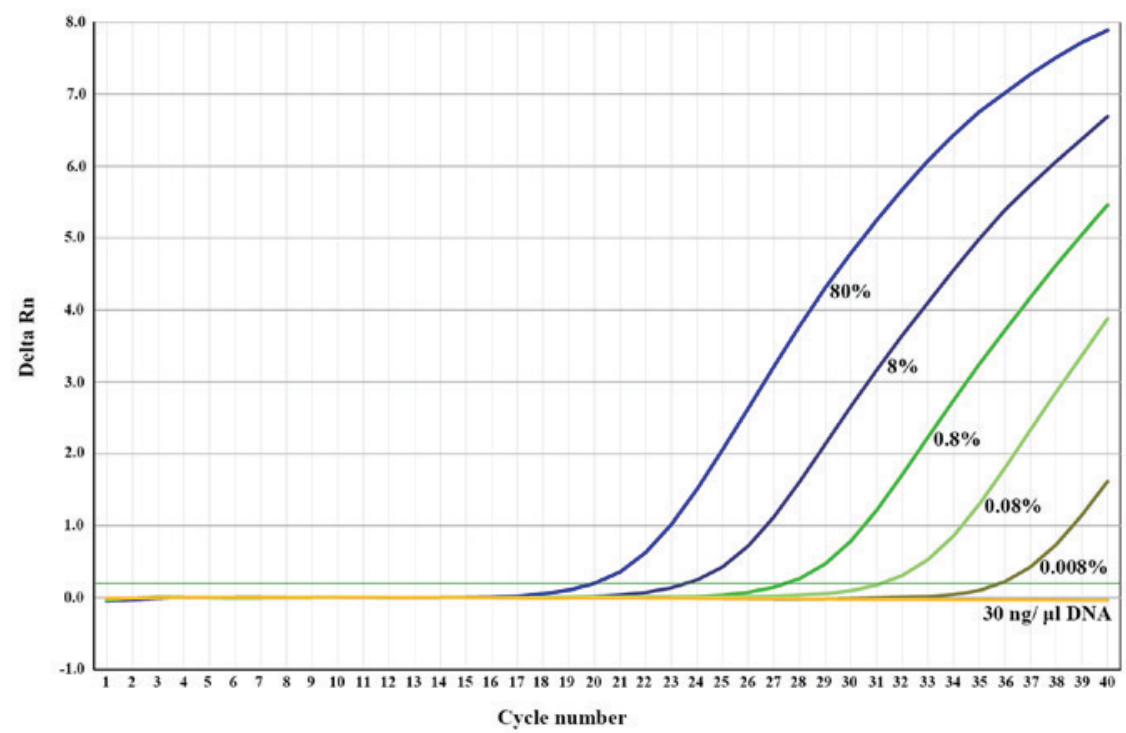

Figure 2. Sensitivity of the BRAF V600E mutation detection by RFLP-ARMS quantitative PCR. Mixing the mutant-encoding plasmid (50,000, 5,000, 500, 50 or 5 copies) with wild-type genomic DNA (30 ng $/ \mu 1$ ), corresponding to $80,8,0.8,0.08$ and $0.008 \%$ mutation rate. RFLP-ARMS, restriction fragment length polymorphism-amplification refractory mutation system; PCR, polymerase chain reaction. The horizontal green line represents the threshold.

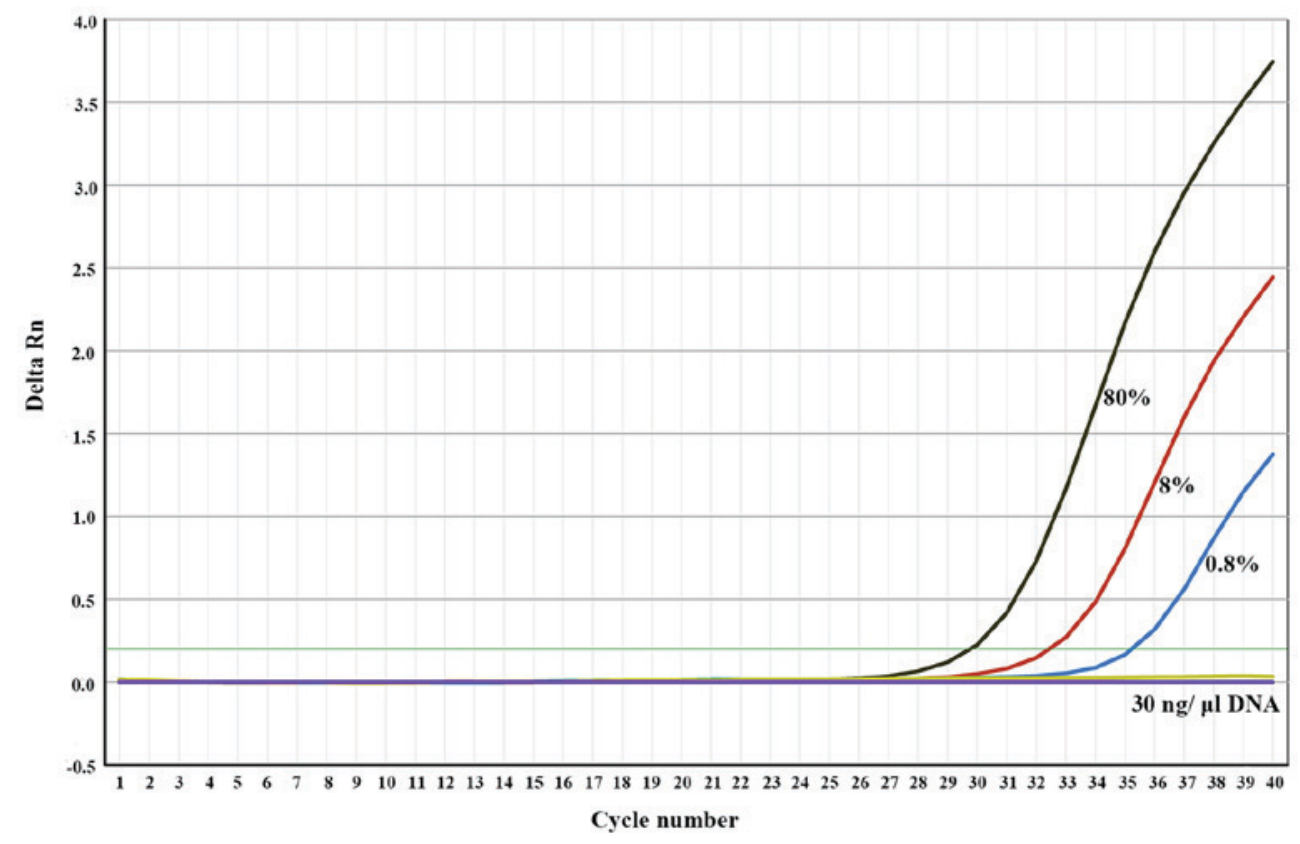

Figure 3. Sensitivity of the BRAF V600E mutation detection by ARMS TaqMan PCR. Mixing the mutant-encoding plasmid (50,000, 5,000, 500, 50 or 5 copies) with wild-type genomic DNA (30 $\mathrm{ng} / \mu \mathrm{l}$ ), corresponding to $80,8,0.8,0.08$ and $0.008 \%$ mutation rates. AMRS, amplification refractory mutation system; PCR, polymerase chain reaction. The horizontal green line represents the threshold. Mutation rates of 0.08 and $0.008 \%$ did not generate an amplified signal.

machine used was ABI-PRISM 3730 (Applied Biosystems; Thermo Fisher Scientific, Inc.) and the analysis software was DNASTAR (v.5.0; DNASTAR, Inc.).

Statistical analysis. Fisher's exact test was used to compare the sensitivity difference of the two methods (RFLP-ARMS TaqMan PCR and PCR sequencing) in the detection of clinical samples with V600E mutation rates $<5 \%$. $\mathrm{P}<0.05$ was considered to indicate a statistically significant difference. SPSS for Windows was used (version 23.0; IBM Corp., Armonk, NY, USA).

\section{Results}

Specificity. To assess the specificity of the RFPL-ARMS TaqMan PCR method, RFLP-ARMS TaqMan PCR was performed using wild-type genomic DNA $(2-200 \mathrm{ng} / \mu \mathrm{l})$. By testing all the wild-type genomic DNA (2-200 ng) cases, the cut-off $\Delta \mathrm{Cq}$ value was determined to be $3 \mathrm{Cq}$ below the lowest $\Delta \mathrm{Cq}$ value observed; the final cut-off $\Delta \mathrm{Ct}$ value was determined to be 14 . The $\Delta \mathrm{Cq}$ values were then calculated as the difference between the mutant and control $\mathrm{Cq}$ values. If the difference was smaller than the cut-off $\Delta \mathrm{Ct}$ value, 
the sample was classified as positive (a larger $\Delta \mathrm{Cq}$ reflected the presence of fewer mutant alleles). If the difference was larger than the cut-off point, the sample was classified as mutation-negative or beyond the limits of detection.

Sensitivity. To determine the minimal detection limit of the RFPL-ARMS TaqMan PCR method, a mimic human genomic DNA panel containing the mutant plasmid and normal wild-type human genomic DNA was used. The results revealed that the mutation-enriched PCR sequencing method exhibited increased sensitivity compared with direct PCR sequencing (Fig. 1), and was able to identify mutations making up $\sim 1 \%$ of the total genomic DNA content. Furthermore, the RFLP-ARMS TaqMan PCR assay was demonstrated to be a sensitive and practical method to screen for the BRAF V600E mutation. As indicated in Fig. 2, this RFLP-ARMS TaqMan PCR method allowed the detection of mutants within mixed samples containing $<0.01 \%$ of the V600E mutation (corresponding to $<10$ copies), while $0.8 \%$ V600E mutations were detected by ARMS TaqMan PCR, but 0.08 and $0.008 \%$ gave no amplification signal (Fig. 3).

Mutation analysis of clinical samples. RFLP-ARMS TaqMan PCR and PCR sequencing was performed on 53 clinical samples. Among them, 21 samples were identified to be positive for the BRAF V600E mutation by RFLP-ARMS TaqMan PCR, while only 18 positive samples were identified by PCR sequencing (Table I). The three discordant samples were then analyzed by Droplet Digital PCR (ddPCR; QX200, Bio-Rad Laboratories, Inc., Hercules, CA, USA). The results indicate that the mutation frequency of the three samples was 3.8, 1.2 and $0.6 \%$, respectively, and the results $(3.8,1.2$ and $0.6 \%)$ indicate that the samples were positive for the BRAF V600E mutation, which verified the sensitivity of RFLP-ARMS TaqMan PCR. The result of Fisher's exact test revealed a significant difference between the two methods in detecting low-frequency mutations $(<5 \%)$. Future experiments will use a larger sample size, which may result in increased statistical significance.

\section{Discussion}

For mutation detection, direct sequencing is a straightforward and commonly-used method (48-50). The present study described a novel mutation-enriched PCR sequencing method and indicated that it was able to detect mutant alleles that represented $>10 \%$ of the total genomic DNA content. This strategy is therefore more sensitive compared with direct PCR sequencing, which has a lower detection limit of $25-30 \%(10,51)$. The mutation-enriched PCR sequencing method of the present study was more practical compared with direct PCR sequencing of clinical samples, as it required fewer steps. It is difficult to obtain homogeneous tumor samples in the clinical setting, and the sequencing reaction may fail due to an excess of wild-type sequences (52). Therefore, it is critical to develop more sensitive genotyping methods.

Furthermore, the present study described a second novel method that combines a modified RFLP analysis and ARMS TaqMan qPCR to screen for the BRAF V600E mutation without any post-PCR processing. In our previous
Table I. Comparison of RFLP-ARMS TaqMan PCR and PCR sequencing for BRAF V600E mutation detection.

\begin{tabular}{|c|c|c|c|}
\hline \multirow[b]{2}{*}{ RFLP-ARMS TaqMan PCR } & \multicolumn{2}{|c|}{$\begin{array}{c}\text { PCR } \\
\text { sequencing }\end{array}$} & \multirow[b]{2}{*}{ Total } \\
\hline & + & - & \\
\hline+ & 18 & 3 & 21 \\
\hline- & 0 & 32 & 32 \\
\hline Total & 18 & 35 & 53 \\
\hline
\end{tabular}

RFLP, restriction fragment length polymorphism; ARMS, amplification refractory mutation system; PCR, polymerase chain reaction; +, positive; -, negative.

investigations, we found that when we introduced an additional mismatch at the 3 '-end, there was a marked decrease (The Cq value increased) in the sensitivity of the ARMS qPCR method (unpublished). In the present study, the RFLP primers were introduced into the ARMS TaqMan qPCR to improve the sensitivity. In contrast to general mutation-enriched PCR, a restriction enzyme was used to digest the wild-type DNA, enhancing the proportion of mutant alleles prior to the PCR amplification step. This protocol has the following advantages: Firstly, the restriction enzyme digestion step enhances the specificity by removing the wild-type genomic DNA and enriching the mutant allele; secondly, the sensitivity was additionally improved by using RFLP primers with a Tm that was higher (by $5^{\circ} \mathrm{C}$ ) compared with that of the ARMS primers, which amplified a longer fragment; thirdly, the digestion and PCR reactions were performed in a single tube, avoiding the requirement for any post-PCR processing and decreasing the risk of PCR product contamination; finally, the RFLP and ARMS PCR steps were independent reactions. Together, these benefits ensure that the RFLP-ARMS TaqMan PCR assay described in the present is simple to use and amenable to high-throughput operation.

The results also revealed that the RFLP-ARMS TaqMan PCR assay was able to detect $0.1 \%$ mutant alleles in a background of $\sim 20$ copies of total genomic DNA. The sensitivity and selectivity were significantly higher compared with those achieved by the existing sequencing-based methods. Using this method, 53 melanoma samples were successfully screened for the BRAF V600E mutation. The RFLP-ARMS TaqMan PCR method of the present study identified 21 mutation-positive samples. A total of 18 of these samples were identified by direct PCR sequencing, indicating the high potential of the protocol. The mutation frequency of the three discordant samples was analyzed, which verified that the more sensitive qPCR method was able to detect mutations in samples containing only a small proportion of mutant alleles.

In summary, the novel RFLP-ARMS TaqMan PCR protocol described in the present study offers a means to improve the sensitivity and specificity of mutation detection, and may be a promising method for screening mutant alleles in cancer samples that contain relatively few mutant cells. 


\section{Acknowledgements}

Not applicable.

\section{Funding}

The present study was supported by the NationalHigh-tech R\&D Program of China (863 program; grant no. 2011AA02A115).

\section{Availability of data and materials}

All datasets generated or analyzed in the present study are included in this published article.

\section{Authors' contributions}

YZ, WL and SCY collected tissue samples and wrote the article. SQ, TY and JH contributed to study design, the majority of the experiments, data analysis and article-writing. JZ, LG, $\mathrm{XH}$ and WC participated in the study design, performed the Droplet Digital PCR experiment, data analysis and interpretation and revised the manuscript.

\section{Ethics and consent to participate}

The study protocol was approved by the Ethics Committee of The Third Affiliated Hospital of Sun Yat-sen University, and written informed consent was obtained from all patients.

\section{Consent for publication}

All the study participants have approved the publication of this manuscript.

\section{Competing interests}

The authors declare that they have no competing interests.

\section{References}

1. Davies H, Bignell GR, Cox C, Stephens P, Edkins S, Clegg S, Teague J, Woffendin H, Garnett MJ, Bottomley W, et al: Mutations of the BRAF gene in human cancer. Nature 417: 949-954, 2002

2. Greenman C, Stephens P, Smith R, Dalgliesh GL, Hunter C, Bignell G, Davies H, Teague J, Butler A, Stevens C, et al: Patterns of somatic mutation in human cancer genomes. Nature 446: 153-158, 2007.

3. Garnett MJ and Marais R: Guilty as charged; B-RAF is a human oncogene. Cancer Cell 6: 313-319, 2004.

4. Wan PT, Garnett MJ, Roe SM, Lee S, Niculescu-Duvaz D, Good VM, Jones CM, Marshall CJ, Springer CJ, Barford D, et al: Mechanism of activation of the RAF-ERK signaling pathway by oncogenic mutations of B-RAF. Cell 116: 855-867, 2004.

5. Hartsough EJ, Basile KJ and Aplin AE: Beneficial effects of RAF inhibitor in mutant BRAF splice variant-expressing melanoma. Mol Cancer Res 12: 795-802, 2014.

6. Dzienis MR and Atkinson VG: Response rate to vemurafenib in patients with BRAF-positive melanoma brain metastases: A retrospective review. Melanoma Res 24: 349-353, 2014.

7. Le K, Blomain ES, Rodeck U and Aplin AE: Selective RAF inhibitor impairs ERK1/2 phosphorylation and growth in mutant NRAS, vemurafenib-resistant melanoma cells. Pigment Cell Melanoma Res 26: 509-517, 2013.

8. Huang T, Zhuge J and Zhang WW: Sensitive detection of BRAF V600E mutation by Amplification Refractory Mutation System (ARMS)-PCR. Biomark Res 1: 3, 2013.
9. Chen D, Huang JF, Xia H, Duan GJ, Chuai ZR, Yang Z, Fu WL and Huang Q: High-sensitivity PCR method for detecting BRAF V600E mutations in metastatic colorectal cancer using LNA/DNA chimeras to block wild-type alleles. Anal Bioanal Chem 406: 2477-2487, 2014.

10. Zhang X, Zhao Y, Wang M, Yap WS and Chang AY: Detection and comparison of epidermal growth factor receptor mutations in cells and fluid of malignant pleural effusion in non-small cell lung cancer. Lung Cancer 60: 175-182, 2008.

11. Asano H, Toyooka S, Tokumo M, Ichimura K, Aoe K, Ito S, Tsukuda K, Ouchida M, Aoe M, Katayama H, et al: Detection of EGFR gene mutation in lung cancer by mutant-enriched polymerase chain reaction assay. Clin Cancer Res 12: 43-48, 2006.

12. Ikryannikova LN, Afanas'ev MV, Akopian TA, Il'ina EN, Kuz'min AV, Larionova EE, Smirnova TG, Chernousova LN and Govorun VM: Mass-spectrometry based minisequencing method for the rapid detection of drug resistance in Mycobacterium tuberculosis. J Microbiol Methods 70: 395-405, 2007.

13. Turner DJ,Zirvi MA, Barany F, Elenitsas R and Seykora J: Detection of the BRAF V600E mutation in melanocytic lesions using the ligase detection reaction. J Cutan Pathol 32: 334-339, 2005.

14. Ye Y, Wang D, Su C, Rong T and Guo A: Combined detection of $\mathrm{p} 53, \mathrm{p} 16, \mathrm{Rb}$, and EGFR mutations in lung cancer by suspension microarray. Genet Mol Res 8: 1509-1518, 2009.

15. Whitcombe D, Theaker J, Guy SP, Brown T and Little S: Detection of PCR products using self-probing amplicons and fluorescence. Nat Biotechnol 17: 804-807, 1999.

16. Mattarucchi E, Marsoni M, Binelli G, Passi A, Lo Curto F, Pasquali F and Porta G: Different real time PCR approaches for the fine quantification of SNP's alleles in DNA pools: Assays development, characterization and pre-validation. J Biochem Mol Biol 38: 555-562, 2005.

17. Wolstencroft EC, Hanlon K, Harries LW, Standen GR, Sternberg A and Ellard S: Development of a quantitative real-time polymerase chain reaction assay for the detection of the JAK2 V617F mutation. J Mol Diagn 9: 42-46, 2007.

18. Thelwell N, Millington S, Solinas A, Booth J and Brown T: Mode of action and application of Scorpion primers to mutation detection. Nucleic Acids Res 28: 3752-3761, 2000.

19. Newton CR, Graham A, Heptinstall LE, Powell SJ, Summers C, Kalsheker N, Smith JC and Markham AF: Analysis of any point mutation in DNA. The amplification refractory mutation system (ARMS). Nucleic Acids Res 17: 2503-2516, 1989.

20. Jarry A, Masson D, Cassagnau E, Parois S, Laboisse C and Denis MG: Real-time allele-specific amplification for sensitive detection of the BRAF mutation V600E. Mol Cell Probes 18: 349-352, 2004.

21. van Es JM, Polak MM, van den Berg FM, Ramsoekh TB, Craanen ME, Hruban RH and Offerhaus GJ: Molecular markers for diagnostic cytology of neoplasms in the head region of the pancreas: Mutation of K-ras and overexpression of the p53 protein product. J Clin Pathol 48: 218-222, 1995.

22. Tan YH, Liu Y, Eu KW, Ang PW, Li WQ, Salto-Tellez M, Iacopetta B and Soong R: Detection of BRAF V600E mutation by pyrosequencing. Pathology 40: 295-298, 2008.

23. Li J, Wang L, Jänne PA and Makrigiorgos GM: Coamplification at lower denaturation temperature-PCR increases mutation-detection selectivity of TaqMan-based real-time PCR. Clin Chem 55: 748-756, 2009.

24. Li J, Wang L, Mamon H, Kulke MH, Berbeco R and Makrigiorgos GM: Replacing PCR with COLD-PCR enriches variant DNA sequences and redefines the sensitivity of genetic testing. Nat Med 14: 579-584, 2008.

25. Milbury CA, Correll M, Quackenbush J, Rubio R and Makrigiorgos GM: COLD-PCR enrichment of rare cancer mutations prior to targeted amplicon resequencing. Clin Chem 58: 580-589, 2012.

26. Pritchard CC, Akagi L, Reddy PL, Joseph L and Tait JF: COLD-PCR enhanced melting curve analysis improves diagnostic accuracy for KRAS mutations in colorectal carcinoma. BMC Clin Pathol 10: 6, 2010.

27. Zuo Z, Chen SS, Chandra PK, Galbincea JM, Soape M, Doan S, Barkoh BA, Koeppen H, Medeiros LJ and Luthra R: Application of COLD-PCR for improved detection of KRAS mutations in clinical samples. Mod Pathol 22: 1023-1031, 2009.

28. Montgomery J, Wittwer CT, Palais R and Zhou L: Simultaneous mutation scanning and genotyping by high-resolution DNA melting analysis. Nat Protoc 2: 59-66, 2007.

29. Zhou L, Wang L,Palais R, Pryor R and Wittwer CT: High-resolution DNA melting analysis for simultaneous mutation scanning and genotyping in solution. Clin Chem 51: 1770-1777, 2005. 
30. Amicarelli G, Shehi E, Makrigiorgos GM and Adlerstein D FLAG assay as a novel method for real-time signal generation during PCR: Application to detection and genotyping of KRAS codon 12 mutations. Nucleic Acids Res 35: e131, 2007.

31. Efrati E, Elkin H, Peerless Y, Sabo E, Ben-Izhak O and Hershkovitz D: LNA-based PCR clamping enrichment assay for the identification of KRAS mutations. Cancer Biomark 8: 89-94, 2010-2011.

32. Kobunai T, Watanabe T, Yamamoto Y and Eshima K: The frequency of KRAS mutation detection in human colon carcinoma is influenced by the sensitivity of assay methodology: A comparison between direct sequencing and real-time PCR. Biochem Biophys Res Commun 395: 158-162, 2010.

33. Li J, Wang F, Mamon H, Kulke MH, Harris L, Maher E, Wang L and Makrigiorgos GM: Antiprimer quenching-based real-time PCR and its application to the analysis of clinical cancer samples. Clin Chem 52: 624-633, 2006.

34. Fariña Sarasqueta A, Moerland E, de Bruyne H, de Graaf H, Vrancken T, van Lijnschoten $\mathrm{G}$ and van den Brule AJ: SNaPshot and StripAssay as valuable alternatives to direct sequencing for KRAS mutation detection in colon cancer routine diagnostics. J Mol Diagn 13: 199-205, 2011.

35. Magnin S, Viel E, Baraquin A, Valmary-Degano S, Kantelip B, Pretet JL, Mougin C, Bigand M, Girardo B, Borg C and Ferrand C: A multiplex SNaPshot assay as a rapid method for detecting KRAS and BRAF mutations in advanced colorectal cancers. J Mol Diagn 13: 485-492, 2011.

36. ZinskyR,Bölükbas S,BartschH,Schirren Jand Fisseler-Eckhoff A: Analysis of KRAS mutations of exon 2 Codons 12 and 13 by SNaPshot analysis in comparison to common DNA sequencing. Gastroenterol Res Pract 2010: 789363, 2010.

37. Grau O and Griffais R: Diagnosis of mutations by the PCR double RFLP method (PCR-dRFLP). Nucleic Acids Res 22 5773-5774, 1994

38. Newton CR, Graham A, Heptinstall LE, Powell SJ, Summers C, Kalshekerl N, Smith JC and Markham AF: Analysis of any point mutation in DNA. The amplification refractory mutation system (ARMS). Nucleic Acids Res 17: 2503-2516, 1989.

39. Toyooka S, Tsukuda K, Ouchida M, Tanino M, Inaki Y, Kobayashi K, Yano M, Soh J, Kobatake T, Shimizu N and Shimizu K: Detection of codon 61 point mutations of the K-ras gene in lung and colorectal cancers by enriched PCR. Oncol Rep 10: 1455-1459, 2003.

40. Behn M, Qun S, Pankow W, Havemann K and Schuermann M: Frequent detection of ras and p53 mutations in brush cytology samples from lung cancer patients by a restriction fragment length polymorphism-based 'enriched PCR' technique. Clin Cancer Res 4: 361-371, 1998.

41. Behn M and Schuermann M: Sensitive detection of p53 gene mutations by a 'mutant enriched' PCR-SSCP technique. Nucleic Acids Res 26: 1356-1358, 1998.

42. Scobie GA, Ho ST, Dolan G and Kalsheker NA: Development of a rapid DNA screening procedure for the Factor V Leiden mutation. Clin Mol Pathol 49: M361-M363, 1996.
43. Bai RK and Wong LJ: Detection and quantification of heteroplasmic mutant mitochondrial DNA by real-time amplification refractory mutation system quantitative PCR analysis: A single-step approach. Clin Chem 50: 996-1001, 2004.

44. Board RE, Thelwell NJ, Ravetto PF, Little S, Ranson M, Dive C, Hughes A and Whitcombe D: Multiplexed assays for detection of mutations in PIK3CA. Clin Chem 54: 757-760, 2008.

45. Marghoob AA, Koenig K, Bittencourt FV, Kopf AW and Bart RS Breslow thickness and clark level in melanoma: Uupport for including level in pathology reports and in American Joint Committee on Cancer Staging. Cancer 88: 589-595, 2000.

46. Livak KJ and Schmittgen TD: Analysis of relative gene expression data using real-time quantitative PCR and the 2(-Delta Delta C(T)) method. Methods 25: 402-408, 2001

47. Kimura H, Kasahara K, Kawaishi M, Kunitoh H, Tamura T, Holloway B and Nishio K: Detection of epidermal growth factor receptor mutations in serum as a predictor of the response to gefitinib in patients with non-small-cell lung cancer. Clin Cancer Res 12: 3915-3921, 2006.

48. Kalikaki A, Koutsopoulos A, Hatzidaki D, Trypaki M, Kontopodis E, Stathopoulos E, Mavroudis D, Georgoulias V and Voutsina A: Clinical outcome of patients with non-small cell lung cancer receiving front-line chemotherapy according to EGFR and K-RAS mutation status. Lung Cancer 69: 110-115, 2010.

49. Uruga H, Kishi K, Fujii T, Beika Y, Enomoto T, Takaya H, Miyamoto A, Morokawa N, Kurosaki A and Yoshimura K: Efficacy of gefitinib for elderly patients with advanced non-small cell lung cancer harboring epidermal growth factor receptor gene mutations: A retrospective analysis. Intern Med 49: 103-107, 2010.

50. Tamura K, Okamoto I, Kashii T, Negoro S, Hirashima T, Kudoh S, Ichinose Y, Ebi N, Shibata K, Nishimura T, et al: Multicentre prospective phase II trial of gefitinib for advanced non-small cell lung cancer with epidermal growth factor receptor mutations: Results of the West Japan Thoracic Oncology Group trial (WJTOG0403). Br J Cancer 98: 907-914, 2008.

51. Endo K, Konishi A, Sasaki H, Takada M, Tanaka H, Okumura M, Kawahara M, Sugiura H, Kuwabara Y, Fukai I, et al: Epidermal growth factor receptor gene mutation in non-small cell lung cancer using highly sensitive and fast TaqMan PCR assay. Lung Cancer 50: 375-384, 2005.

52. Zhao J, Xie F, Zhong W, Wu W, Qu S, Gao S, Liu L, Zhao J, Wang M, Zhou J, et al: Restriction endonuclease-mediated real-time digestion-PCR for somatic mutation detection. Int $\mathrm{J}$ Cancer 132: 2858-2866, 2013.

This work is licensed under a Creative Commons Attribution-NonCommercial-NoDerivatives 4.0 International (CC BY-NC-ND 4.0) License. 